\title{
Phosphatidylinositol kinase is reduced in Alzheimer's disease
}

Citation for published version (APA):

Jolles, J., Bothmer, J., Markerink, M., \& Ravid, R. (1992). Phosphatidylinositol kinase is reduced in Alzheimer's disease. Journal of Neurochemistry, 58(6), 2326-2329. https://doi.org/10.1111/j.14714159.1992.tb10981.x

Document status and date:

Published: 01/01/1992

DOI:

10.1111/j.1471-4159.1992.tb10981.x

Document Version:

Publisher's PDF, also known as Version of record

\section{Please check the document version of this publication:}

- A submitted manuscript is the version of the article upon submission and before peer-review. There can be important differences between the submitted version and the official published version of record.

People interested in the research are advised to contact the author for the final version of the publication, or visit the DOI to the publisher's website.

- The final author version and the galley proof are versions of the publication after peer review.

- The final published version features the final layout of the paper including the volume, issue and page numbers.

Link to publication

\footnotetext{
General rights rights.

- You may freely distribute the URL identifying the publication in the public portal. please follow below link for the End User Agreement:

www.umlib.nl/taverne-license

Take down policy

If you believe that this document breaches copyright please contact us at:

repository@maastrichtuniversity.nl

providing details and we will investigate your claim.
}

Copyright and moral rights for the publications made accessible in the public portal are retained by the authors and/or other copyright owners and it is a condition of accessing publications that users recognise and abide by the legal requirements associated with these

- Users may download and print one copy of any publication from the public portal for the purpose of private study or research.

- You may not further distribute the material or use it for any profit-making activity or commercial gain

If the publication is distributed under the terms of Article $25 \mathrm{fa}$ of the Dutch Copyright Act, indicated by the "Taverne" license above, 


\title{
Phosphatidylinositol Kinase Is Reduced in Alzheimer's Disease
}

\author{
J. Jolles, J. Bothmer, M. Markerink, and *R. Ravid \\ Deparment of Neuropsychology and Psychobiology, University of Limburg. Maastricht; and \\ *The Netherlands Institute for Brain Research, Amsterdam. The Netherlands
}

\begin{abstract}
Phosphatidylinositol (PI) kinase and PI phosphate (PIP) kinase activities were measured in postmontem samples of brain tissute from patients with Alzheimer"s disease and nondemented control subjects. A membrane-free cylosolic fraction from four neocortical locations, with exogenous inositol lipids as the substrate, was used. Tissue from patients with Alzheimer's disease was characterized by reduced PIP formation; the reduction was $50 \%$ in prefrontal cortex, temporal cortex, and parietal cortex and 409 in precentral gyrus. In contrast, no alterations were found in PI bisphosphate formation in these four neacortical locations. The specific changes in Pl kinase but not PIP kinase activity suggest that the findings may thave functional relevance to the involvement of brain membrane processes in Alzheimer"s disense. Key Words: Phosphatidylinositol kinase-Phosphatidylinositol phosphate kinaseBrain cortex-Alzheimer's disease. Jolles J. et al. Phosphatidylinositol kinase is reduced in Alzheimer's disease. $J$. Newrochen. 58 , $2326-2329(1992)$.
\end{abstract}

Alzheimer's disease (AD) is a neurodegenerative disease and the most common cause of adult-onset dementia. The etiology and pathogenesis are presently not known. Interest in brain membrane phospholipids was aroused several years ago in relation to the hypothesis of a cholinergic dysfunction in $\mathrm{AD}$ (see, e.g. Bartus et $1 ., 1982$ ) and the notion that these neurons utilize choline for the formation of the membrane phospholipid phosphatidylcholine (Wurtman et al, 1990\%. Alterations in phosphatidylcholine and its metabolites and in other phospholipids in AD brains have now been described (see, e.g., Miatto et al., 1986; Pettegrew et al., 1989, Blusztain et al., 1990). Charges in other phospholipids, notably phosphatidylinositol (PI) and its breakdown product, myo-inositol, have also been investigated in AD and in normal aging (Stokes et al., 1983; Stokes and Hawthome, 1987). Such findings may have functional significance because the interconversion of PI into PI phosphate (PIP) and PI bisphosphate (PIP) and the breakdown of the latter substance into diacylglycerol and inositol trisphosphate are key processes in neuronal function (for review, see Abdell-Latif. 1986: Berridge, 1987: Downes and MacPhee, $1990)$.
The present study was undertaken to investigate whether inositol phosphollipid phosphorylating activity is different in brains from patients with $\mathrm{AD}$ as compared with brains from nondemented control subjects. Considering the rapid breakdown of inositol phospholipids after death (Lin et al., 1990 ) and after low-energy periods in vitro (Jolles et al., $1981 b$ ), we chose to measure enzyme activity rather than analyze phospholipid contents. Brain samples were obtained by rapid autopsy (within $4-6 \mathrm{~h}$ after death). AD and control subjects were matched for age to reduce possibly confounding factors such as duration of disease and interaction between age and disease. Four neocortical locations were compared to detect possible regional variations like those observed in old animals (Bothmer et al., 1990a). PI kinase and PIP kinase were studied in a membrane-free supermatant of $\mathrm{AD}$ and control brain, with exogenous PI and PIP as lipid substrates.

\section{MATERIALS AND METHODS}

\section{Subjects}

Brain samples from five patients with $\mathrm{AD}$ (three males and two females; mean age, 65.2 years) and five control subjects (three males and two females; mean age, 69 years) were used in this study (Table 1). Patients and controls were individually matched for age and postmortem interval. Brain tissue was obtained from The Netherlands Brain Bank (The Netherlands Institute for Brain Research). The mean postmortem interval was $5 \mathrm{~h}$ for AD subjects and $5 \mathrm{~h}$ 15 min for the controls. The patients with $A D$ were clinically diagnosed as "probable Alzheimer"s disease" (McKhann et al., 1984; American Psychiatric Association, 1987), and this was verified by postmortem neuropathological examination. Control subjects had no history of dementia or any other neurological or psychiatric disorder.

\section{Brain dissection}

Brain specimens for analysis of inositol phospholipid kinase activity were obtained from four neocortical locations
Recived February 14, 1992; accepted February $20,1992$.

Address correspondence and reprint requests to Prof. Dr. J. Jolles at Deparment of Neuropsychology and Psychobiology. Uniwersity of Limburg. P.O. Box 616.6200 MD Masstricht, The Netherlands.
Abbrevations used: $\mathrm{AD}$, Alzheimer's disease; PI, phosphatidylinositol; PIP, phosphatidylinositol phosphate, PIP, , phosphatidylinositol bisphosphate. 
TABLE 1. Autopsy data of subjects used in the study

\begin{tabular}{|c|c|c|c|c|c|c|c|}
\hline $\begin{array}{l}\text { Subject, } \\
\text { experimental } \\
\text { no. }\end{array}$ & Patient no. & $\begin{array}{c}\text { Age } \\
\text { (years) }\end{array}$ & Sex & $\begin{array}{c}\text { Brain } \\
\text { weight } \\
\text { (g) }\end{array}$ & $\begin{array}{l}\text { Postmortem } \\
\text { delay } \\
\text { (h min) }\end{array}$ & $\mathrm{pH}$ & Cause of deatly \\
\hline \multicolumn{8}{|l|}{ Controls } \\
\hline $\mathrm{Cl}$ & $88-29.4$ & 60 & $\mathbf{M}$ & 1,350 & 600 & 6.45 & $\begin{array}{l}\text { Septic shock following aorla } \\
\text { valve inplantation }\end{array}$ \\
\hline $\mathrm{C} 2$ & $88-194.3$ & 65 & $\mathrm{M}$ & 1,310 & 515 & 6.18 & Heart failure \\
\hline $\mathrm{C} 3$ & $88-328.1$ & 66 & $F$ & 1,100 & 615 & 6.24 & Metastases of breast cancer \\
\hline $\mathrm{C} 4$ & $88-366.0$ & 71 & $\mathrm{~F}$ & 1,240 & 505 & 6.28 & Sepsis and cardiogenic shock \\
\hline $\mathrm{C} 5$ & $88-255.2$ & 73 & $\mathrm{M}$ & 1,340 & 415 & 6.89 & $\begin{array}{l}\text { Cerebral infarct without } \\
\text { evident cause }\end{array}$ \\
\hline $\mathrm{C} 6$ & $88-2311.2$ & 73 & M & 1,410 & 520 & 6.93 & Postoperative heart failure \\
\hline \multicolumn{8}{|l|}{$A D$} \\
\hline $\mathrm{Ai}$ & $89-15.4$ & 59 & $\mathrm{~F}$ & 780 & 505 & 6.59 & Cardiac arrest \\
\hline A2 & $89-112$ & 64 & M & 1,210 & 530 & 6.21 & $\begin{array}{l}\text { Collum fracture; died after } \\
\text { operation }\end{array}$ \\
\hline A3 & $89-10$ & 68 & $\mathbf{F}$ & 895 & 545 & 6.52 & Bronchopneumonia \\
\hline A4 & $88-209$ & 70 & $\mathrm{M}$ & 1,075 & 430 & 6.38 & Cachexia \\
\hline A5 & $86-272$ & 65 & $\mathrm{M}$ & 1,360 & 400 & - & $\begin{array}{l}\text { Cachexia/lung emboli/ } \\
\text { delhydration }\end{array}$ \\
\hline A6 & $88-216$ & 72 & $M$ & 1,040 & 445 & 6.89 & Pneumonia and cachexia \\
\hline
\end{tabular}

Crude enzyme fractions from the frontal superior gyrus and the parietal lobe were prepared from subjects $\mathrm{Cl}-\mathrm{C5}$ and $\mathrm{Al}-\mathrm{A} 5, \mathrm{crude}$ enzyme fractions from the precentral gyrus were prepared from subjects $\mathrm{Cl}-\mathrm{C} 4$ and $\mathrm{C} 6$ and $\mathrm{A} /-\mathrm{A} 5$, and crude enzyme fractions from the medial temporal gyrus were prepared from patients $C 1-C 5$ and $A 2-A 6$.

in the right hemisphere: (a) the frontal superior gyrus, (b) the precentral gyrus, (c) the medial temporal gyrus, and (d) the parietal lobe. The leptomeninges were removed, and samples were excised. These samples were sealed in plastic, rapidly frozen by immersion in liquid nitrogen, and stored at $-80^{\circ} \mathrm{C}$ until use.

\section{Preparation of crude enzyme fraction}

Pieces of $\sim 0.5 \mathrm{~g}$ were excised from the tissue samples and thawed in a water bath at $0^{\circ} \mathrm{C}(20 \mathrm{~min})$. The tissue was homogenized in a medium consisting of $0.32 \mathrm{M}$ sucrose, I $\mathrm{m} M$ EGTA, and $50 \mathrm{~m} M$ Tris- $\mathrm{HCl}(\mathrm{pH} 7.4)$ in a total volume 10 times the brain tissue volume, by 12 up-and-down strokes of a Potter-Elvehjem Teflon-glass homogenizer (radial clearance, $0.125 \mathrm{~mm} ; 700 \mathrm{rpm}$ ), followed by homogenization by hand in a glass-glass homogenizer with 3 up-anddown strokes. The homogenate was centrifuged for $60 \mathrm{~min}$ at $100,000 \mathrm{~g}$, and the resulting membrane-free supernatant was used as the crude enzyme fraction. This fraction was stored at $-80^{\circ} \mathrm{C}$. There was no decline in enzyme activity after $\mathbb{\text { month }}$ of storage.

\section{PI kinase and PIP kinase assay}

Inositol phospholipid kinase activity was measured as described before (van Dongen et al., 1986; Moritz et al., 1990), with some modifications. The incubation volume (normally $25 \mu$ l) was doubled for the PIP kinase assay to reduce interassay variability. Supernatant fractions of 15 or $30 \mu \mathrm{l}$ (10 and $20 \mu \mathrm{g}$ of protein, respectively) were preincubated for 2 min. Lipid precursors [ $20 \mu M$ PI or $20 \mu M$ PIP (Sigma), solubilized in $0.1 \%$ Triton $\mathrm{X}-100,50 \mathrm{mM}$ Tris- $\mathrm{HCl}$, and $\mathbb{1}$ mMEGTA, pH 7.4] were added $15 \mathrm{~s}$ before the phosphorylation reaction was started by addition of ATP. The reaction lasted $1 \mathrm{~min}$. Incubations were performed under the following conditions: $7.5 \mu M$ ATP, $2-3 \mu \mathrm{Ci}$ of $\left[\gamma^{32} \mathrm{P}\right] \mathrm{ATP}$ $(\sim 3,000 \mathrm{Ci} / \mathrm{mmol}$; Amersham, U.K.), $50 \mathrm{~m} M$ Tris-HCl
(pH 7.4), $10 \mathrm{~m} M \mathrm{MgCl}_{2}, 1 \mathrm{~m} M$ EGTA, and $0.02 \%$ Triton $\mathrm{X}-100$. The reaction was terminated, and the extraction and further analysis of the ${ }^{32} \mathrm{P}$ incorporated into PIP and $\mathrm{PIP}_{2}$ were performed, as described elsewhere (Jolles et al., $1981 \mathrm{a}$; Bothmer et al., 1990b). Protein content was determined according to the method of Lowry et al. (1951).

\section{RESULTS}

The results of the PI kinase assay in brain samples from patients with $A D$ and controls are shown in Fig. IA. A significant difference between $A D$ and control patients was found in the four neocortical locations tested $[p<0.01$ by multivariate analysis of variance (MANOVA)]. The AD group was characterized by a reduction in $\left[{ }^{32} \mathrm{P}\right] \mathrm{PIP}$ formation by
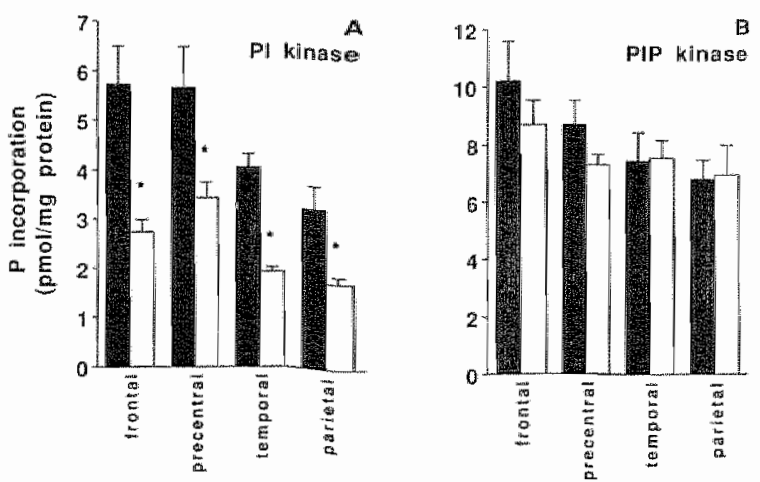

FIG. 1. Pl kinase (A) and PIP kinase (B) activities in crude cytoplasmic fractions from four neocortical regions of $A D$ brains and age-matched controls, expressed as picomoles of $\mathrm{P}_{\mathrm{i}}$ incorporated into $\mathrm{PI}$ monophosphate per milligram of protein. Data were analyzed by one-way analysis of variance: " $p<0.01$. 
50 (prefrontal cortex, temporal cortex, and parietal cortex) or $40 \%$ (precentral cortex). In the control samples, there was a regional variation in PIP formation: [ ${ }^{32} \mathrm{PJPIP}$ formation was significantly lower in the temporal and parietal cortex than in the prefrontal and precentral cortex $[p<0.01$ by the procedure of Siegel and Catellan (1988)]. There were no such differences in the $A D$ samples.

The results of the PIP kinase assay with tissue from patients with $\mathrm{AD}$ and controls are shown in Fig. 1B. There were no differences between $A D$ and control subjects in any of the four structures; the decreased $\left[^{32} \mathrm{PJPI}_{2}\right.$ formation in the four structures did not reach statistical significance.

\section{DISCUSSION}

The present study shows that a crude cylosolic PI kinase fraction obtained from neocortical structures taken from brains of patients with $\mathrm{AD}$ has $\sim 50 \%$ less activity than similar fractions obtained from control brains. This effect appears to be quite specific as there was no decrease in PIP kinase activity. The difference between the two patient groups cannot be ascribed to factors such as age and postmortem delay because the groups had been matched for these factors. The postmortem interval ( $4-6 \mathrm{~h}$ ) was very short, which is an advantage considering the rapid breakdown of the various compounds after death. The large SD values in the studies of Stokes and Hawthorne (1987), in which they measured the absolute concentrations of free myo-inositol and inositol phospholipid-bound inositol in brains from patients with $\mathrm{AD}$ and control subjects, are probably caused by the postmortem interval $(7-83 \mathrm{~h})$, as they suggested. In this study we measured enzyme activities and thus circumvented the problem that the levels of PIP and $\mathrm{PIP}_{2}$ - and to a lesser extent $\mathrm{Pl}$-are dependent on the postmortem interval. A rapid postrnortem breakdown of the polyphosphoinositides in rat brain has been described in previous studies (Dawson and Eichberg, 1965; Jolles et al., 1981b); Jolles et al. (1981b) showed that $50 \%$ of the labile form of PIP and PIP $P_{2}$ was no longer detectable within $2 \mathrm{~min}$. Likewise, Lin et al. (1990) provided evidence for a very rapid hydrolysis of rat brain $\mathrm{PIP}_{2}$ within minutes after decapitation.

Both the present results and the findings of Stokes and Hawthorne (1987) suggest that the inositol phospholipid systern may be involved in the pathogenesis of $A D$. It is of importance in this respect that other investigators have also found evidence for an involvement of membrane phospholipids and their metabolites in AD. Several research groups, using ${ }^{31}$ P NMR spectroscopy, have found elevations in levels of phosphomonoesters, e.g., phosphocholine, early in the course of the disease, followed by an elevation in levels of phosphodiesters, e.g., glycerol-3-phosphorylcholine (Barany et al., 1985; Miatto et al., 1986; Brown et al., 1989; Blusztajn et al., 1990). In addition, AD brain appears to be characterized by a decrease in levels of phosphatidylcholine, phosphatidylethanolamine, phosphatidylserine, and cholesterol (Pettegrew et al., 1989). Apart from phospholipids, phosphorylated proteins are implicated in $A D$ as well. For example, the phosphorylation of protein tyrosine (Shapiro et al, 1991) and of microtubule-associated proteins (Hanger et al., 1991 ) has received much attention over the last years. It remains to be established whether there is any relation between these changes and the findings reported in the present article.
The change in PI kinase activity is of potential relevance because of the large effect found: A reduction of $50 \%$ in enzyme activity is substantial in view of the fact that neocortical tissue can be expected to contain cell types that do not degenerate in $\mathrm{AD}$. Thus, if the reduced PI kinase activity is confined to a particular cell type or types, the effect may be still greater. Furthermore, inositol phospholipids play a key role in impulse initiation and propagation and thus with intrinsic neuronal and brain functions (for reviews, see Abdel-Latif, 1986; Berridge, 1987). A large decrease in PIP formation can therefore be expected to have a widespread intluence on membrane function because the pathway that leads to $\mathrm{PIP}_{2}$ formation is blocked. This may result in a blockade of $\mathrm{PIP}_{2}$ hydrolysis and thus inhibit the formation of the second messengers inositol trisphosphate and diacylglycerol. It is relevant in this respect that reduced numbers of inositol trisphosphate binding sites have been found in the parietal cortex and hippocampus of patients with AD (Young et all., 1988).

With respect to the biochemical mechanisms underlying the reduced incorporation of ${ }^{32} \mathrm{P}$ into PIP, it is possible that the $\mathrm{AD}$ brain samples are characterized by a reduced quantity of PI kinase, by changes in enzyme kinetics, or by the presence or absence of cofactors. Questions as to the type of PI kinase involved are also relevant in view of the fact that two different types of PI kinase are known, namely, the kinase that phosphorylates PI at the 4 position of the inositol ring (the so-called "PI 4-kinase") and the one that phosphorylates the 3 position ("PI 3-kinase"). This difference is of importance because the two kinases are implicated in different functions in the cell (Downes and MacPhee, 1990). Involvement of the PI 3-kinase would be of great relevance because this kinase is suggested to be involved in cell growth and in the maintenance of the cytoskeleton (Carpenter and Cantley, 1990). The fact that the present findings were obtained with a membrane-free supernatant suggests that the kinase responsible for these findings might be the PI 3-kinase. Research is in progress to investigate whether the present findings are due to changes in the activity of PI 3-kinase or PI 4-kinase.

The finding that the differences between $A D$ brains and control brains were quite similar for the four structures tested is indicative of a global degeneration of the neocortex. Indeed, the patients were in the terminal stage of the disease, i.e., stage 7 on the Global Deterioration Scale (Reisberg et al., 1983) when most neocortical tissue is known to be involved. Research is planned to compare the tertiary association zones investigated in the present study with the primary sensory cortex and limbic zones and with the cerebellum. A comparison with the latter structure is judged to be especially relevant because this region is not pathologically affected in $A D$. In addition, other neurological disease groups (Parkinson's disease and multi-infarct dementia) are investigated in order to ascertain the specificity of the observed changes in PI kinase activity. In conclusion, specific alterations in inositol phospholipid phosphorylation have been found in the present study. The findings may be important because of the key role played by inositol phospholipids in neuronal functioning.

\section{REFERENCES}

Abdel-Latif A. A. (1986) Calcium-mobilizing receptors, polyphosphoinositides, and the generation of second messengers. PharMacol Rev. 38, 227-272. 
American Psychiatric Association (1987) Diagnostic and Stotistical Manual of Mental Disorders, 3rd ed., revised. American Psychiatric Association, Washington, DC.

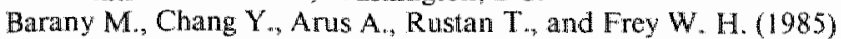
Increased glycerol-3 phosphorylcholine in post mortenn Alzheimer brain. Lancet 1, 517.

Bartus R. T., Dean R. L. III, Beer B., and Lippa A. S. (1982) The cholinergic hypothesis of geriatric memory dysfunction. Science $217,408-417$.

Berridge M. J. (1987) Inositol triphosphate and diacylglycerol: two interacting second messengers. Anmu. Rev. Biachem. 56, 159193.

Blusztajn J. K., Lopez-Gonzales-Coviella L., Logue M., Growdon J. H., and Wurtman R. J. (1990) Levels of phospholipid calabolic intermediates, glycerolphosphocholine and glycerolphosphoethanolamine, are elevated in brains of Alzheimer's disease but not of Down's syndrome patients. Brain Res. 536, 240244.

Bothmer J., Markerink M., and Jolles J. (1990a) Age related changes in the interconversion of inositol phospholipids in the rat brain cortex, in From Gene to Man (Van Bezooijen C. F. A., Ravid $\mathbb{R}_{\text {, }}$ and Verhofstad A. A. J., eds), pp. 186-189. J. H. Pasmans Publishers, The Hague, The Netherlands.

Bothmer J., Markerink M., and Jolles J. (1990b) Phosphatidic acid and polyphosphoinositide formation in a broken cell preparation from rat brain: effects of different incubation conditions. Neurochem. Int. 17, 27-33.

Brown G. G., Levine S. R., Gorell J. M., Pettegrew J. W., Gdowski B. J., Bueri J. A., Helpern J. A., and Welch K. M. A. (1989) In vivo "PNMR profiles of Alzheimer's disease and multiple subcortical inferct dementia. J. Neurol 39, 1423-1427.

Carpenter C. L. and Cantley L. C. (1990) Phosphoinositide kinases. Biochemistry 29, $11147-11156$.

Dawson R. M. C. and Eichberg J. (1965) Diphosphoinositide and triphosphoinositice in animal tissue: extraction, estimation and changes post-mortem. Biochem. J. 96, 634-643.

Downes C. P. and MacPhee C. H. (1990) myo-Inositol metabolites. as celfular signals, Eur. J. Biochem. 193, 1-18.

Hanger D. P.. Brion J.-P., Gallo J.-M. Carns N. J., Luthert P. J, and Anderton B. H. (1991) Tau in Alzheimer"s disease and Down's syndrome is insoluble and abnormally phosphorylated. Biochem. J. 275, 99-104.

Jolles I., Zwiers H., Dekker A., Wirtz K. W. A., and Gispen W. H. (1981 a) ACTH) - 24 affects protein phosphorylation and polyphosphoinositide metabolism in the rat brain. Biochem. $J$. $194,283-291$

Jolles J., Schrama L. H., and Gispen W. H. (1981b) Calcium-dependent turnover of brain polyphosphoinositidles in vitro after prelabelling in vivo. Biochim. Biophys. Acta 666, 90-98.

Lin T. N., Sun G. Y., Premkumar N., MacQuarry R. A., and Carter S. R. (1990) Decapitation-induced changes in inositol phos- phates in rat brain. Biochem. Biophys. Res. Commen. 167, 1294-1301.

Lowry O. H., Rosebrough N. J., Farr A. L., and Randall R. I. (1951) Protein measurement with the Folin phenol reagent. J. Biol. Chem. 193, 265-275.

McKhann G., Drachman D., Folstein M., Katzman R., Price D., and Stadlan E.M. (1984) Clinical diagnosis of Alzheimer"s disease: report of the NINCDS-ADRDA Work Group under auspices of Department of Health and Human Services "lask Fonce on Alzheimer's Disease. Newrology 34, 939-945.

Miatto $O_{\text {, }}$, Gonzalez R. G., Bounanno F., and Growden J. H. (1986) In vitro ${ }^{31}$ PNMR spectroscopy detects altered phospholipid metabolism in Alzheimer"s disease. Can. J. Neurosc. 13, $535-539$.

Moritz A., De Graan P. N. E. Ekhart P. F. Gispen W. H., and Wirtz K.W. A. (1990) Purification of a phosphatidylinositol 4-phosphate kinase from bovine brain membranes. $/$. Newrochem. 54, 351-354.

Pettegrew J. W., Moossy J., Panchalingham K., Martinez J., Strychor S., McKeag G., Brantoover G., and Boller F. (1989) Correlation of phospholipids and senile plaques in Alzheimer's disease. (Abstr) Neurology 39 (Suppl 1), 396.

Reisberg B., Ferris S. H., DeLeon M. J., and Crook T. (1983) Clinical presentation, diagnosis and symptomatology of age-associated cognitive decline and Alzheimer"s disease "in $\mathrm{Alz}$ heimer's Disease (Reisberg B., ed), pp. 173-183. The Free Press, New York.

Shapiro I. P., Masliah E., and Saitoh T. (1991) Altered protein tyrosine phosphorylation in Alzheimer"s disease. $J$. Neurochem. 56, 1154-1162.

Siegel S. and Castellan N. J. (1988) Nonparametric Statist ics for the Behavioral Sciences. MoGraw-Hill, New York.

Stokes C. E and Hawhorne J. N. (1987), Reduced phosphoinositide concentrations in anterior temporal cortex of Alzheimerdiseased brains. Newochem. 48, 1018-1021.

Stokes C. E., Gillon K. R. W., and Hawthorne J. N. (1983) Free and total lipid myo-inositol concentrations decrease with age in human brain. Biochim. Biophys. Acta 753, 136-138.

van Dongen C. J., Kok J. W., Schranna L. H., Oestreicher A. B., and Gispen W. H. (1986) Immunochemical characterization of phosphatidylinositol 4-phosphate kinase from brain. Biocherm. I. 233, 859-864.

Wurtman R. J., Blusztain J. K., Ulus $\Perp$. H., Lopez Gonzalez-Conviella I., Buyukuysal L. R., Growdion J H., and Slack B. E (1990) Choline metabolism in cholinergic neurons: implications for the pathogenesis of neurodegenerative diseases, in $\mathrm{Ad}$ vances in Neurology. Fol. 51: Alzhemer's Disedese (Wurtman R. J., Corkin S. H., Growdon J. H., and Ritter-Walker E., eds), pp. 17-125. Raven Press, New York.

Young L. T., Kish S. H., Li P. P., and Warsh J. J. (1988) Decreased brain ['H]inositol 1,4,5-trisphosphate binding in Alzheimer's diseasc. Neurosci Lef 94, 198-202. 